\title{
Renewing and improving the business model toward sustainability in theory and practice
}

\author{
Mara Del Baldo ${ }^{1 *}$ and Maria-Gabriella Baldarelli ${ }^{2}$
}

\begin{abstract}
The paper aims to analyse and discuss the evolution towards a sustainable business model and to focus on the motivations and the implications on the mission, the governance and the accountability of companies. Moreover, the theoretical framework of values-based, ethical and sustainable leadership has been used as interpretative key for the case-study analysis. After presenting the literature review, the second part of the work is based on the inductive approach applied to the analysis of the experience of an Italian medium-sized company (SGR Group) belonging to the energy sector (oil \& gas). Recently this company has started a new project aimed at renewing its business model and deepening its sustainability orientation, which has already been experienced for years. The project is finalized at identifying and assessing vices and virtues which affect the governance and the leadership model, as well as the company's stakeholders engagement processes. The case exemplifies a resilience capability derived from a sustainable business model activated through relationships among internal and external stakeholders and supported by an ethical-based transformational leadership model which, in turn, derives from and nurtures the coherence among the mission-governance and accountability model.

Specifically, the analysis confirms the propositions drawn from the literature review relative to the fact that the coherence among mission, governance and accountability is a key driver for effective business model and that sustainable business models derive from and are characterized by sustainable leadership models, which include transformational, ethical-based and values-virtues-driven leadership.
\end{abstract}

Keywords: Business model, Sustainability, Sustainable business model, Sustainable leadership, Values-based leadership, Mission, Governance, Accountability

\section{Introduction}

Before analyzing as a company's business model "should be", this paper focuses on the "sense" of the business model (BM) and the needs of modern times. We briefly present some guidelines that underline a new way of understanding the market and the company within the same market. These guidelines emphasize the importance of individuals/entities, who/which have the propensity to very strong partnerships. This propensity is not only aimed to an economic return but is intended to build deeply personal relationships. This tendency becomes a fundamental element to make the functioning of the

\footnotetext{
* Correspondence: mara.delbaldo@uniurb.it

'Department of Economics, Society and Politics, University of Urbino Carlo

Bo, Urbino, PU, Italy

Full list of author information is available at the end of the article
}

market effective (Bruni \& Zamagni, 2007; Bruni, 2008). Even the re-reading of some business and economic paradigms, underlines this need of the existence of this type of inclination. That is, without companies characterized by a propensity to always cooperate, the market would crash, because it would lack the "lubricant" that makes possible its process.

Moving from the logic of the market which is passing from a set of contracts to a set of relations (Bruni 2008), a profound rethinking of the business models is required. This is because the previous paradigms showed a lot of problems not easily remediable, such as: the culture of the reject instead of that of inclusion; the development of pure philanthropy and the race to sustainability without a real project, that is oriented to develop strategies to enable future generations to really take advantage 
of a more equitable world, both from an ecological and social justice point of view (Baldarelli, 2005). Moreover, there is the need for a new vocabulary, that focuses on the person inside of the market instead of goods. This process requires a long and difficult reflection but It cannot be delayed if we want that the enterprises should be able to produce wealth using positive and virtuous structures and not "vicious" structures, such as the exploitation of human and natural resources.

The concept of sustainability adopted in this paper is a concept of strong sustainability (Del Baldo et al., 2015) that is based on gratuity and reciprocity aspects (Bruni, 2008), in which the "intentions" are important in a first phase, but more important are actions concretely implemented. In the sustainability development process that are pursuing particularly the so-called "rich" countries, we want to understand how enterprises are implementing their business models using good praxis and not only general declarations of intents. There are some enterprises that implemented new sustainable business models, such as: ethics finance, fair trade and economy of communion (Baldarelli, 2005; Baldarelli et al., 2015). But we can also find some essay of business model, which applies these aspects in enterprises, which implement the logic of reciprocity also based on gratuity (Bruni 2008).

Starting from these premises the paper aims to analyze and discuss the evolution toward a sustainable-driven business model (BM) and to focus on the motivations and the implications on the mission, the governance and the accountability of a company (Matacena, 2010).

Moreover, since the business culture is based on values and principles which drive business strategies, policies and actions (Gray et al., 1997; Broadbent 1998 and 2015), the theoretical framework of values-based, ethical and sustainable-driven leadership will be presented and used as interpretative key for the analysis of a single-case study (Malloch, 2009; Capaldi, 2013; Ruisi, 2010; Hoivik von Weltzien, \& Melé, 2009; Hoivik von Weltzien, 2014).

Accordingly, after introducing the literature review, the second part of the work is based on the inductive approach (namely, the action research approach; Benbasat et al., 1987; Sankaran et al., 2003; Contrafatto, 2011 Spence \& Gray, 2008; Bebbington et al., 2009) applied to the analysis of the "evolutionary" experience of an Italian medium-sized company (SGR Group) belonging to the energy sector oil \& gas. Recently, this multi-utility company has started a new project aimed at renewing its business model and deepening its sustainability orientation, which has already been experienced for years (Baldarelli et al., 2014). Notably, the project (which primarily involves the top management is finalized at identifying and assessing vices and virtues which affect the governance and the leadership model, as well as the company's stakeholders engagement processes.
The study presents and discusses the first findings obtained through the aforementioned empirical analysis, which is still in a preliminary stage of development. Despite the limitations related to the use of a qualitative approach, based on a single case study, and to the fact the research is still in progress, the works have implications both on the scientific and managerial/operational level. In fact previous studies did not address this topic using twofold interpretive keys (sustainability business model and virtues-based/ethical based and sustainable leadership); at the same time, the research project contributes to improve the learning of the sustainabilityoriented process and sustainable leadership in the real business context, thus opening new trajectories for the fruitful convergence between theory and practice.

\section{Theoretical framework}

\section{Sustainable business models}

A business model (BM) can be defined in many ways because literature presents various perspectives on this topic and a shared framework has not yet been established (Timmers, 1998; Teece, 2010; Zott \& Amit, 2010; Zott et al., 2011; Morris et al., 2013; Brougham, 2012; Leisenring et al., 2012; Page, 2014; SingletonGreen, 2014; Penman 2007). For instance Magretta's (2002), Zott and Amit (2010) and Beattie and Smith (2013) define business models as a holistic description on 'how a firm does business' while Stewart \& Zhao, 2000 consider BM as a description (Applegate, 2000; Weill \& Vitale, 2001) or, alternatively as: a representation (Morris, Schindehutte, \& Allen, 2005; Shafer, Smith, \& Linder, 2005); an architecture (DubossonTorbay, Osterwalder \& Pigneur, 2002; Timmers, 1998); a conceptual tool or model (George \& Bock, 2009; Osterwalder, Pigneur, \& Tucci, 2005); a structural template (Amit \& Zott, 2001); a method (Afuah \& Tucci, 2000); a framework (Afuah, 2004); a pattern (Brousseau \& Penard, 2007), and a set (Seelos \& Mair, 2007). Teece (2010) claims that a BM articulates how the company will convert resources and capabilities into economic value. Richardson (2008) proposes a consolidated view of the components of a business models, as: the value proposition (i.e. the offer and the target customer segment), the value creation and delivery system, and the value capture system. Adopting an activity based perspective, Zott and Amit (2010) includes the selection of activities ('what'), the activity system structure ('how'), and who performs the activities ('who'). The conceptual construct used in this study considers a BM as "the rationale of how an organisation creates, delivers and captures value" or, in other words, as "the organisation's core logic for creating value" (Linder \& Cantrell, 2000: 12). Value is intended as sustainable value, thus expressed in terms of economic, social, ethical environmental performances. 
Many studies have focused on the analysis of business cases based on unique and successful BMs (Magretta, 2002; Morris, Schindehutte \& Allen, 2005). If one considers the BM as a reflection of the strategy implemented by a company (Shafer et al., 2005; Casadeus-Masanell \& Ricart, 2010) and the "how" an organization tailors its business model and strategy to respond to the external environment (and the relative risks and opportunities it faces) it becomes then important to understand how the $\mathrm{BM}$ is bound and it is linked to the mission, governance and the accountability and to what extent it is resilient. The elements of the trinomial mission-corporate governance-accountability model are in fact tied by reciprocal relations, since in every enterprise there exists an explicit and coherent coordination between mission, governance and accountability (Matacena, 2010). Mission is intended a synthesis of the company aims; corporate governance as the command structure and of the government present in the company; accountability as the company's informative responsibility (to take into account and to give account to) of the company.

Drawing from the aforementioned literature, it can be assumed that the sustainable business model is characterized by the consistency among the three elements of the company: mission, governance and accountability. Therefore, our first proposition is that "the coherence among mission, governance and accountability is a key driver for effective BM".

Moreover, the capacity of the BM to adapt to changes (e.g., in the availability, quality and affordability of inputs) affects the organization's longer term viability (Walker \& Salt, 2006; Walker, 2015). Consequently we assume that this resilience capability characterizes sustainable business model (SBMs).

"The world needs a comprehensive reassessment of our understanding of value - its parameters and its effects - to restore trust in economic and business decision-making, and achieve investment that contributes towards financial stability and sustainable development. We must ensure that business models sing to the tune of a value creation model fit for the $21^{\text {st }}$ Century" (Jonathan Labrey, Chief Strategy Office, International Integrated Reporting Council -IIRC, Paris, 6 May, 2015) (IIRC, 2013; IIRC, 2013b). The need for developing SBMs and their implementation in practice has been pointed out since many approaches towards CSR have been predominantly inward-oriented and not capable of linking firms' social responsibilities to the core business and the value creation processes (Visser, 2011). Consequently more outward-oriented conceptions of CSR are necessary through SBMs that take firms' value creation processes as a starting point and escape the more narrow concept of CSR (see
Bocken et al., 2014; Schaltegger et al., 2012; Looser \& Wehrmeyer, 2015; Del Baldo, 2014 and 2016b).

A SBM is a model where sustainability concepts (to create value for various stakeholders and the natural environment) shape the driving force of the firm and its decision making (Abdelkafi, \& Täusher, 2015). Specifically it encompasses a wide range of change within the organization, as well as in its external network, than traditional business models. Necessary steps are: developing company culture toward sustainability; framing company values and translating them into principles or/and business practices; implementing sustainable strategy: a vision and mission linked to all activities of the organization; acquiring appropriate skills and knowledge across the value chain through external resources and internal training; (create green business cases): green business model must be financially sustainable; involve customer to better understand their needs and expectations of a sustainable company (Boons, Lüdeke-Freund 2013).

Comparable conceptual notions of SBMs do not exist today (Lüdeke Freund, 2009; Schaltegger et al., 2016) because sustainable development denotes a process where ecological, economic and social values are balanced in continuous action (Lélé, 1991), that is a process that involves inter-organizational networks formed by different stakeholder (firms, public institutions, banks, entrepreneurial and civic associations, etc.) and wider societal systems (Del Baldo, 2016a).

SBMs archetypes are introduced and categorized to develop a common language that can be used to accelerate the development of SBMs in research and practice, such as: maximise material and energy efficiency; create value from 'waste'; substitute with renewable and natural processes; deliver functionality rather than ownership; adopt a stewardship role; encourage sufficiency; re-purpose the business for society/environment; and develop scale-up solutions (Bocken, et al., 2014).

Within the literature strands on sustainable entrepreneurship and corporate sustainability management severel connections to corporate sustainability, including sustainable innovation, can be found (Boons and Lüdeke-Freund 2013; Schaltegger et al., 2012).

For achieving sustainability a firm has to transform its entire business logic; a BMS is built upon the creation of value to the customers, the value captured by the firm, and the value to the natural environment (Abdelkafi, \& Täusher, 2015). The BM perspective helps to better explore and understand how different types of sustainable innovations (technological innovation; see Wells, 2008; organizational innovation Birkin, Cashman, et al. 2009a; 2009b) can be developed (Lovins et al., 1999; Burritt \& Schaltegger, 2010; Charter et al., 2008; Wells, 2008). Since societal and cultural demands of 
sustainable development evolve outside the economic sphere, organizational change in business enterprises (Birkin et al., 2009a, 2009b) they rest on structural or cultural BM's attributes or are derived from the external socio-economic environment or internal organizational capabilities (Stubbs \& Cocklin, 2008).

A research agenda on SBMs is provided by Boons \& Lüdeke-Freund (2013) who point out that the empirical research helps to shed some light on the state-of-the-art of corporate sustainability management, sustainable organizational development and sustainable innovation in daily business (Tukker et al., 2008; Stubbs \& Cocklin, 2008), to inquire the extent to which BMs allow, or hamper, specific types of innovations (Johnson, 2010) and to demonstrate how to translate social and environmental value creation into economic profit and competitive advantage to build the 'business case for sustainability' (Dyllick \& Hockerts, 2002; Salzmann et al., 2005; Schaltegger et al., 2012). Through the empirical analysis focused on case studies Stubbs \& Cockin (2008) verify that organizations adopting a SBM must develop internal (structural and cultural) capabilities to achieve firm-level sustainability and collaborate with key stakeholders to achieve sustainability for the socio-economic and environmental system they belong to.

The new BMs for sustainability are fashioned through the interactions between individuals and groups inside and outside companies (Roome \& Louche, 2016). Basing their research on case studies, authors show the elements that contributed to a complex process (based on identifying, translating, embedding, and sharing of transformation) toward SBMs which requires the building of networks and collaborative practices for learning and action around a new vision.

Finally, a further stream of literature deals with BMs related to social value creation (Seelos \& Mair, 2005, 2006; Johnson, 2010). Organizational innovations are a form of corporate self-reflection and corporate social innovations are providing solutions to alleviate others/ urgent social problems. Changing the focus of value creation is thus the primary purpose of BM management and innovation (Seelos \& Mair, 2005). The premise is to develop self-sustaining instead of profit maximizing businesses, giving space to entrepreneurs and managers to focus their BMs on social and environmental issues and to create value for the wide spectrum of stakeholders.

\section{Sustainable business models and sustainable leadership}

The way in which SBMs are constructed by actors involved in value creation is an important topic for research (Boons \& Mendoza, 2010) which has not yet been sufficiently investigated. With this respect, the sustainable leadership model is strictly linked to SBMs since entrepreneurial and managerial leadership play a key role in developing an authentic sustainability-oriented strategy (Del Baldo, 2016a forthcoming). Leadership has a crucial role in shaping ethical organisational culture through leaders' moral behaviour, corporate mission, vision and values, ethical criteria for recruiting/selection/ promotions, evaluation processes and monitoring, ethical training programs, applying ethical values to decision making, everyday routine and in intra-organisation procedures and structures (Melé, 2012).

Leadership ethics tend to emphasise the leaders' behavior and their values (Liu, 2007; Kaptein, 2009; Lloyd \& Mey, 2010; Bouckaert, 2011; Hoivik von Weltzien, 2014). Moral leadership is inspired by constitutive moral elements: innovation, intuition and imagination (Hoivik, 2014). Moral imagination entails perceiving norms, social roles, and relationships entwined in managerial decision-making. Moreover, it involves the ability to envision and evaluate new models that create new possibilities to reframe problems and create new solutions in ways that are economically viable and morally justifiable (Werhane, 1999). Moral creativity fosters dynamic and innovative CSR strategies and actions and is linked to responsible and sustainable leadership (Visser, 2011; Von Ahsen, 2015). The organisational culture imbued with moral leadership enjoys several benefits: understanding of the interdependence between stakeholders; learning environment; respect and trust; cooperation; responsibility and accountability (Hoivik \& Melé, 2009; Del Baldo, 2016 - forthcoming).

The ability to "walk the talk of morals" is emphasised when maintaining trustworthiness and model attractiveness (Bass \& Steidlmeier, 1999; Simons, 1999; Choi \& Mai-Dalton, 1998) and is positively related to charismatic and transformational leadership (Choi, 2006; Liu, 2007; Olsen, 2010; Brown, 2011; Palshikar, 2007). Charismatic leaders are capable of turning problems into opportunities and resources thanks to their ability "to see the world" differently (Bruni \& Sena, 2013; Baldarelli, 2013). They build an energetic and positive attitude in others and inspire them to do their very best by creating a common sense of purpose (Shamir et al., 1993; Cardona, 2000).

The theoretical construct of responsible leadership is characterised by a multilevel approach that places the leader, his/her behaviour, attitudes and choices at the core of the management of a company, a division or a team (Magni \& Pennarola, 2015). Theories on responsible leadership thus emphasise the importance of approaching leadership in the context of stakeholder theory (Bass \& Steidlmeier, 1999; Avery \& Bergsteiner, 2011). Responsible leadership requires leaders to also engage in involving stakeholders with virtue and integrity to build the best community and 
workplace (Jones, 2014). Therefore, it enables the integration of the leaders within the stakeholder community. The competencies of responsible leadership are centered on communication, involvement of people and creating a corporate culture based on values and moral convictions (Magni \& Pennarola, 2015).

The responsible leadership model rests on five pillars: stakeholder consideration and ethical climate; integrity and justice; role modeling and empowerment; climate geared toward diversity and inclusion and long term orientation. Through this model, the responsible leader triggers a resilience path that guides the company toward sustainable development (Magni \& Pennarola, 2015). Accordingly, key factors of leadership style are the people strategy (the human resources management), the culture (which enhances the basic values, such as accountability and transparency). The people strategy is based on the enterprise conceived as a community of people. Therefore, its value is measured based on the commitment in bringing out the skills of employees and this leads to the virtue of humility (Seligman, 2004). Responsible leadership may be widespread within businesses, affecting the different levels: individual (favoring the passage from "me to us" through collaboration and shared responsibility); team (through the development of mutual relations of trust and open communication); organisation (structuring a coherent vision and a mission). It rests on the idea that the responsible person must have flexible thinking (i.e., strategic and systematic) which includes the dimensions of logic (to sort, select, plan), ethics (foresight, transparency and perseverance) and aesthetics. Therefore, it requires specific cardinal virtues, such as prudence and courage (Sansone, 2014; Melé, 2009) which are relevant in the business context both at the individual and organizational level (Baldarelli, 2005; Ruisi, 2010; Del Baldo, 2013).

These virtues are cardinal because they are related to the human faculties that determine the structure from which decisions are made. In this sense, fortitude (courage) is competence for operating decisions; prudence (practical wisdom) is competence for predicting; temperance (moderation) (the habit of self-control) is competence for evaluation and justice (friendship) is integrity for action (Bastons, 2008).

Finally, the theoretical construct of sustainable leadership stresses the leadership role in creating a social capital (Avery \& Bergsteiner, 2011) through cultivating a way of being and acting immersed in sustainability values and a dynamic, inclusive and collaborative process. Therefore, the leader's role does not rest in guiding others, but in guiding with the others (Burns, Vaught, Bauman 2015) as a result of sharing the values of sustainability inside and outside of the company.
Drawing from these literature frameworks, we then derive the second proposition: "sustainable business models derives from sustainable leadership models, which encompasses transformational, responsible, ethical/ moral and values/virtues-driven leadership".

\section{Sustainable business model through sustainable and virtues-driven leadership: The SGR experience} Methodology

As mentioned in the introduction, the research design has been developed through a deductive and inductive approach. The first one was based on the analysis of the literature contributions on BM, SMB and sustainable leadership, while the inductive method is based on the analysis of significant research cases (Yin, 2003; Eisenhardt, 1989; Naumes \& Naumes, 2006) which is presented in the following sections. The case is related to the SGR Group, an Italian company which has been selected for its excellence in the CSR and sustainabilityoriented strategies and actions (Baldarelli \& Del Baldo 2013; Baldarelli et al., 2014). As mentioned in the previous sections the empirical research helps to understand the state-of-the-art of corporate sustainability management (Tukker et al., 2008; Stubbs \& Cocklin, 2008), to inquire the extent to which the SBM drives change (Johnson, 2010) and to demonstrate how to translate social and environmental value creation into economic profit and competitive advantage (Dyllick \& Hockerts, 2002; Salzmann et al., 2005; Schaltegger et al., 2012).

The study of the case follows the action research approach (Benbasat et al., 1987) which is considered particularly useful to improve knowledge in the field of social and environmental research (Contrafatto, 2011; Spence \& Gray, 2008; Bebbington et al., 2009) by addressing attention to corporate characteristics (size, industry, profit or financial performance), contextual factors (country of origin and relative variety of social, political and legal factors, social and political change, economic cycles, cultural, specific events, media pressure, stakeholders power) and internal organizational factors (i.e., company chair and board of directors' orientation, corporate structure and governance procedures; stakeholder involvement; perceived costs and benefits) which influence managers' decisions to adopt sustainability strategies and reporting (Adams, 2002). The action researcher does not stand as an independent observer, but he/she becomes a participant; accordingly, the process of change becomes the object of research (Bensasat et al., 1987). This circumstance is particularly useful in the construction of theory in complex situations (Westbrook, 1994) such us the business contexts (Argyris, 1985; Sankaran \& Tay, 2003) and the organizational change (Kotnour, 2001). 
Starting from 2010 the researchers (belonging to two different Italian university) have been involved in the SGR implementation of the sustainability report and in research projects aimed at analysing: the stakeholder engagement process of the Group; how CSR and sustainability orientation affected/affects the organizational culture and climate; how it modified/modifies the mission and the governance system and, recently, how it affects the leadership style and the BM (this research path is still ongoing).

Accordingly, different tools have been used to gather data: semi-structured interviews addressed to the president (Mrs. M. Dionigi) and the management team (i.e. the Chief Financial Officer and CSR manager) and more than 10 managers (responsible of the different business areas and departments) and 30 internal collaborators directly or indirectly involved in CSR and environmental strategies during monthly company visits (from 2009 till 2016, August); the consultation of corporate websites; document analysis (board of directors minutes, sustainability reports, corporate history books, leaflets relating to sustainability initiatives and projects promoted) and the direct observation and informal conversations among people involved in focus groups workshops, seminars, round table and congress focused on the CSR and sustainability issues in which we participated during the planning and execution stages. In total, more than $600 \mathrm{~h}$ of interviews and direct encounters have been carried out. Information has been transcripted, validated and subject to a coding process.

\section{Company profile}

SGR (Società Gas Rimini) Group is a multi-utility and family-owned company, unlisted, based in Italy, with a long experience in gas distribution (Rimondini, 2009). It was founded in 1956 by A. Domeniconi as the first company in the Emilia Romagna Region dedicated to the distribution of gas for heating and household use with the most innovative plants in Europe. In 1970 these plants were connected to the national methane gas pipeline SNAM.

In over 50 years of business activity, SGR Rimini has grown steadily through acquisitions, the winning of tenders, and strategies for sector diversification. The Group includes several companies and serves respectively 46 municipalities in Italy and 39 in Bulgaria; it has more than 215,000 and 1,351 clients in Italy and Bulgaria. In 2014, SGR Group reached a turnover of over 216 million Euro, had 358 employees and obtained a ROI (Return of Investment) rate of $11.60 \%$ and a ROE (Return on Equity) rate of $12.13 \%$.

Since 1998 the Group has adopted the 9001 system for quality certification (upgraded to Vision 2000 and ISO 9001 standard in the following years). In 2010 it obtained the ISO 14001 (Environmental Management System) and the BS OHSAS 18001 (Occupational Health and Safety Management System) certifications. Its business areas include: sale and distribution of natural gas and electric energy; energy service and assistance in Italy and abroad; assembly and maintenance of solar and conditioning plants and sources of renewable energy; utilities technology and a congress centre.

In 2005 (through an international tender adjudication) begin to construct a gas network for domestic and industrial use in Bulgaria. During its first years the subsidiary City-gas Bulgaria won prestigious awards for its contribution to sustainability in the energy sector. In 2010 SGR acquired the company Technoterm Bulgaria and was funded for the Trakia Project by EBRD/BERS European Bank for Reconstruction and Development and Banca Intesa San Paolo. In 2006 SGR Group won the "Milano Finanza Creatori di Valore" award. Recently, the Group started to distribute methane gas in the Italian isles of Sardinia and started a partnership with the leading Russian methane gas company GasProm.

\section{SGR's mission, governance and accountability}

The SGR Group has always considered corporate social responsibility and sustainability an integral part of its mission, values, and core strategies. Since 2008, it has implemented processes, tools and procedures which represent pieces of a single mosaic of responsible and sustainable business management. The choice of drawing up a sustainability report (the first one was adopted in 2011) is part of an evolving process addressed to responsibility and sustainability started years ago and based on a multiplicity of tools (such as the management and control model for the prevention of corporate crimes - Italian D.lgs 231/01; the ethical code introduced in 2008; the balanced scorecard approach, the business process reengineering) aimed at improving the commitment to stakeholders, enriching the stakeholders dialogue, rethinking the company's aims by pursuing a balance among economic, social, environmental and ethical performance and renewing its business model.

The mission of SGR states: "We are known as an innovative and dynamic multi-utilities company, respectful of the environment which is greatly tied to the territory and the community". The mission is structured around the following "milestones": a) the values profile of the founders and the top management team; and b) an attention to CSR, taking care of the surrounding area, the local community and the environment, the development of human resources, service, transparency and social relations, and the centrality of dialogue with the stakeholders. 
As gathered from the interviews and meetings with the top management and various employees and collaborators, it emerges that SGR puts ideas, strategies and actions before two questions: "Are we dealing with an effective answer with regards the evident or latent expectations of one or more categories of stakeholder?" It "wants to be the company of trust for its clients and the best place in which to work".

The SGR Group's governance is composed of the Board of Directors, that involves 5 members. In the daily activity the decision-making process is orientated by the President (a woman) and the General Director (a man). A specific working group promoted a path of stakeholders dialogue and stakeholders engagement which constitute the essential traits of "SGR's way of being". To respond to and contemporise the stakeholders interests, in the last years SGR has implemented a stakeholders engagement plan, which includes diverse tools of consultation and communication. Mention can be made of Intranet, accessible at all corporate levels; an internal blog; a newsletter; employee satisfaction questionnaires; informative brochures; company notice boards; plenary meetings (once or twice a year) and monthly meetings. Democratic nature, trust and a relational logic are founding principles that have been put into motion in governing the SGR Group. The CSR Manager, introduced since 2010, represents a "corporate presidium" of sustainability, a sort of "relational engine" for the stakeholders engagement and dialogue, who collaborates and interacts on a daily basis with the President and other offices.

Accordingly, with reference to the accountability, the sustainability report (GRI, 2013 -G4) is a driver aimed to support a progressive process which incorporates shared principles, actions and practices of management and sustainable corporate governance.

A summary of commitments to the projects used to internally and externally implement sustainability among collaboration with stakeholders is summed up in the following table (Table 1) with reference to the categories of employees, clients and suppliers, the environment, and institutions and the community.

Finally, among the several projects addressed to client, supplier, employees, local and international community and environment (Baldarelli et al., 2014) one should remark a wide range of activities and in particular: the educational projects addressed to the new generations, developed in collaboration with the local schools and aimed to create and reinforce the students' environmental and responsible education $^{1}$; the conciliation projects of work-life time (i.e. the "enteprise butler"; the summer camps for the children of employees; the "babies in the office"); the market at km zero for domestic spending of employees; the time flexibility and the corporate wellness projects.

\section{Improving SGR's sustainable business model}

Recently (during 2016) the Group started a project aimed at assessing the virtues anchor of its values among the middle and top management (first step) and within all employees (second step). The project - promoted by a group formed by the CFO, the CSR officer, the President and the university researchers - is being developed as a "play" based on sharing common reflection using a model which is represented as a wheel with three concentric circles. In the outer one there are the Group's areas (finance, communications, operations, organization, strategy, planning and control, innovations, human resources management and informative system) and their subdivisions, while in the central one seven virtues (Prudence, Fortitude, Justice, Temperance, Faith, Hope, Charity) and seven vices (ride, avarice, envy, lust, gluttony, wrath and sloth) are included. This "simple" tool is used to capture the leading virtues and values that affect the personal and organization behaviors in the daily activities within the different business area, to bring them out and, by a process of dialogue based on personal relationship and meetings, to share and improve individual and company's virtues and "combat" vices (Fig. 1).

Specifically, its implementation over the next months (but taking into account a medium-long perspective) will drive changes in the way of working and doing business.

In the following part some statements derived from interviews and informal conversations with the SGR CFO and the CSR officer, summarize the main aspects of the evolution over time of the SGR's business models.

"We chose to adopt a different business model, namely a patient business model. Over the years we have favored investments that will bear fruits (in terms of economic, social and environmental performances) in the medium to long term, beyond more than 3 years, such as the awareness-raising and environmental education projects addressed to schools and the research projects with local universities, or the several initiatives that we share with local stakeholders through a plurality of networks in which we took part. Another example of this approach is the new company - Sherden - aimed to introduce the methane gas in Sardinia or the agreement with GazProm allowing us to participate in an international table and to think of a start-up in the chemical sector to introduce sustainable innovation ("the chemical that works") through a project on the bacteria contained in natural gas. This investment did not start on the basis of a budget, but on the basis of a shared idea (SGR Group CFO, March $3^{\text {rd }}, 2016$ ). 
Table 1 SGR sustainability-driven paths

\begin{tabular}{ll}
\hline Commitment & Actions \\
\hline Increase interviews with people & 2005. Introduction of a survey on the internal climate and a \\
Increase the training and awareness of employees regarding the & questionnaire to assess satisfaction \\
themes of safety & 2010. Increasing total number of training hours (internal and \\
Implement the training scheme and apply it to all members of the & external training) \\
companies & 2011. Restyling company intranet and provision of an area dedicated \\
Increase internal communication & advice about improving corporate sustainability. \\
Develop activities to reconcile Life and Work & 2010. Area and plenary meetings to discuss the results of the survey \\
Diffusion of the culture of Sustainability and a corporate atmosphere & and plan actions for improvement \\
based on shared values & 2011. The Mia Voce Project: dedicated to employees' messages and \\
& suggestions. Each month, in agreement with the management, a \\
& theme is proposed and selected to start new project aimed at life \\
& and work reconciliation \\
& 2011. Initiatives regarding information and awareness about sustainability \\
& aimed at internal and external members of the Group.
\end{tabular}

Environment

Adopt new guidelines and procedures relative to environmental management

Increase the activity of awareness about energy saving use

Rationalize energy consumption in Bulgaria

\section{Community and Institutions}

Make channels of communication coherent and transparent, drawing inspiration from the values of Sustainable Development and the participation demands of all interlocutors (clients, suppliers, employees and territory)

Promotion of a dialogue with local, national and international institutions

Management of plants in the territory and protection of the biodiversity of the landscape

Support to the community

Partnership with local, national and international actors

\section{Customer/Supplier}

Define systems of periodic surveys to assess the degree of client satisfaction

Maintain and develop the activity of information aimed at saving Energy, protecting the environment and safety.

Promotion of Energy Efficiency in the final uses

Promoting respect from suppliers for the principles which have inspired the Organizational Model of the SGR Group.

Support the development of eco-sustainability purchasing processes

Define and promote supplier assessment systems

People (employees)

"With the project"cultural innovation and leadership: vices and virtues in corporate governance" SGR questions to understand what are its virtues and its vices, to identify critical points and strengths. The idea is to use this model to improve the governance and leadership and renew the business model. We want to match this model with the Swot analysis, not by reasoning more in terms of sectors of a matrix, but using a flexible tool, based on dialogue and personal
2010. ISO 14001 System of Environmental Management BS OHSAS 18001 Health and Safety Management Systems

2011. "M'illumino di meno". National initiative aimed at making people aware of an intelligent use of electric energy

2011. Relations with schools, public institutions and universities were strengthened through the organisation and promotion of the theme of energy efficiency (i.e. through the project "Renewable Energy and Emission Reduction", promoted by the Municipality of Rimini).

2011. Citygas becomes the official representative in the Bulgaria in raising awareness on energy saving and energy efficiency.

2011. New SGR Services website, company profile, sales leaflets, Calendar and Diary; New layout of Clients' Offices

2011. Energy Efficiency Project in Bulgaria with the EBRD- European Bank for Reconstruction and Development and the Ministry of Bulgaria Project "Natura 2000" http://www.natura.org/

Contribution in favour of the Health Authority of Rimini;

Collaborations and partnership with schools, universities (Bologna, Rimini, Milano-Bocconi), local research centers and other educational bodies in work-related learning projects.

Support to many cultural, civic, sport organisation, onlus, national and international ONG (donations, funds, free usage of company's structure and time and skills of the employees

2010. Half-yearly interviews conducted by the Authorities for Electric Energy and Gas.

Internal interviews has been launched and carried out to clients who have had recent dealings with the companies of the SGR Group 2010. Distribution of Water Conservation Kits to clients

2010. Making end users aware of responsible energy consumption. 2011. Requested adhesion to the Group's principles

Electronic negotiation tools to replace traditional paper-based processes 2011. The launch of the development of a project for supplier assessment 


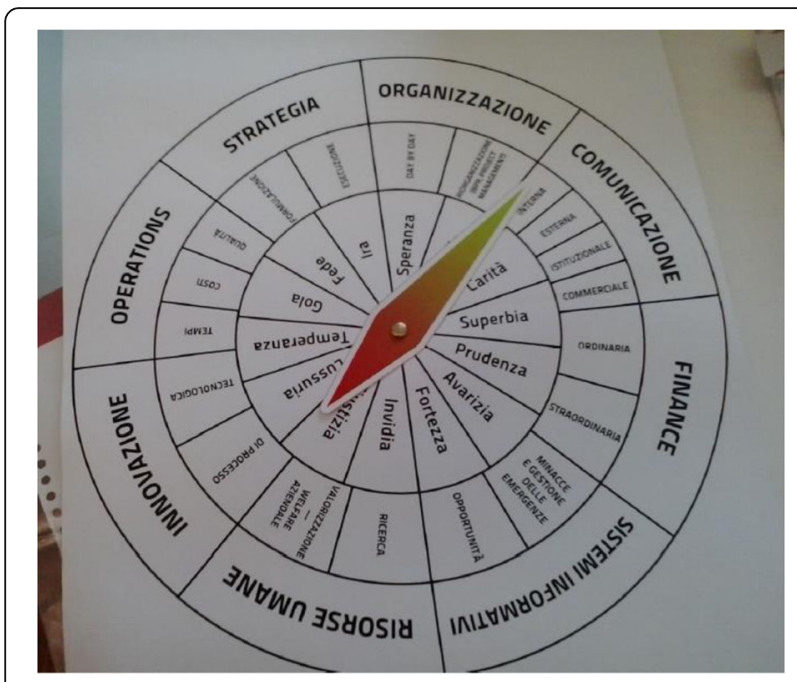

Fig. 1 SGR's virtues and vicious in management perspective

business model. Governance guides the strategy, which in turn guides the operations (marketing, technology, etc.)" (CFO SGR Group, May 17 $\left.{ }^{\text {th }}, 2016\right)$.

"We want to leave a little more for all the future from today: this is the declination of the virtue of prudence, which we share, as well as sloth or apathy is interpreted as resistance to change and justice (in top down, bottom up and cross relations) is understood as the recognition and appreciation of each other's work and working together. Still, temperance in the relationship means to us the most appropriate way to correct the choices and actions of collaborators; charity as care for each other in the extent of the resources used and through a real dialogue; avarice as the absence of generosity; envy as inability to share the good of others; the throat as the inability to gain satisfaction from current achievements and sloth as difficulty in questioning and abandon one's comfort zones" (SGR CSR Officer, May 17th, 2016).

"We want to reward the virtues, not only through monetary awards, but also in terms of valuation and esteem. This project and the model upon which it is found help us to rediscover daily work as a responsible and sustainable game. The model also becomes a gaming tool to create interaction with schools. At the end of the project a reframe of the companies values and virtues will be made through a questionnaire aimed at understanding what virtues are shared, which are present or absent in the company, which stimuli were developed, and what has changed in the daily behavior of each person and in the corporate culture" (SGR Group CEO, May 17th, 2016).
After the presentation of the case, in the next paragraph we are going to discuss the most relevant findings drawn from the analysis.

\section{Discussion}

In SGR the core values (reciprocity, transparency, integrity, coherence, efficiency; sustainability, personal responsibility, respect and valuing people, quality of suppliers) constitute the first level in orienting towards CSR and sustainability, fostering social cohesion and favouring a pathway of social innovation (Martin \& Osberg, 2007; Miller et al., 2012; Nicholls \& Murdock, 2012; EU-Commission, 2012); shared by stakeholders (local public institutions, non profit and civic organizations, schools and universities, etc.) which is summed up in the sustainability report (Baldarelli et al., 2014).

The interviews addressed to the company heads stress how these values (professionalism, dedication to work, simplicity in colleague relations and reliability, which are firstly experienced by the owners, the president (a woman) and the top management - are spread throughout the entire organization, thus reinforcing SGR's corporate culture. Furthermore, they are shared and embedded in the relationships between employees and external stakeholders.

In an interview with the President of the Group - a charismatic leader and reference point for the company - supported by the CFO's transformational style of leadership - values emerge which have been inherited from the founders and interpreted by the actual leader in coherence with the changed internal and external environmental context. She started working in the company from the bottom and thanks to her passion, humility, spirit of sacrifice and a great capacity for listening and interacting, she became the President. Her relational approach has been translated into the principle of the "door being open" to each collaborator. As she said: "I acted as a friend" now "it is the company which acts as a friend". Before (but even now) we were and are still a family". The centrality of relations lies in the centrality of the person: "Over the years the organization has become less hierarchical and increasingly more orientated towards team work, aiming to seek a dynamic balance between singular dimension and plural dimension" (SGR President, 2013).

Accordingly, the words of the chief operating and financial executive officer testify to an exciting corporate development taking place over the years (Rimondini, 2009) thanks to great entrepreneurial skills, and the charisma and dynamism of the founder and his successor (the actual female President).

The responsibility and sustainability orientation influence the micro-organizational processes, the SGR external relationships and its way to generate value trough a 
business model based on a participative process and fair relationships with stakeholders. Through to the relationship-based approach driven by the female president and shared by the CFO, SGR has a strong closeness to its clients and to all stakeholders; it is able to listen, interpret and provide a reply to their respective expectations. Moreover, due to the centrality of values and relationships, and the rootedness, the Group can be appreciated as a company "of the territory" (Del Baldo, 2010) which spreads the culture of sustainability and the common good within the socio-economic fabric through a wide variety of initiatives and new projects.

The leadership does not drive the company in the face of short-term results but casts his gaze away to business development in the long run (Rhode, 2006). Furthermore, it emphasizes mutual trust and growth based on transparency and corporate reputation. SGR "wants to be the company you trust to its customers and the best place to work" (SGR Groups President, May 2015).

\section{Conclusion}

One central goal for companies nowadays is to create shared value (Porter \& Kramer, 2011). Scholars increasingly recognise that business contributions to sustainable development are founded in new business models (Roome \& Louche 2016). Literature identifies many SBMs whose common elements are: the importance of achieving partnership with local organizations, the focus on pre-existent skills of the company, the value creation process in the value constellation, the development of innovative distribution models. Moreover, different contributions point out the need for social innovation and the fact that CSR suffers from a lack of radical innovation.

Accordingly, the question if and to what degree today's companies are already implementing SBMs becomes more and more relevant, as well as how do firms connect the elements of a BM to their innovation attempts. With respect to these priorities, attention on how sustainability is constructed by actors involved in value creation and on how can they encourage changes in the way companies operate to ensure greater sustainability represent an important topic for research (Boons \& Mendoza, 2010) that has been addressed under the theoretical and empirical perspective through this work.

Specifically, the case-analysis confirms the validity of the propositions emerged from the literature review:

Prop. 1: "the coherence among mission, governance and accountability is a key driver for effective business models". (Matacena, 2010).
Prop 2: "sustainable business models derive from and are characterized by sustainable leadership models, which encompassed transformational, responsible, ethical/moral and values-virtues driven leadership" that are concretely implemented and not only theorized" (Bastons, 2008; Magni \& Pennarola, 2015).

The SGR case exemplifies a resilience capability derived from a sustainable business model (SBMs) where innovation and the improvement of the BM is activated through relationships among internal and external stakeholders and are supported by an ethical-based transformational leadership model which, in turn, derives from and nurtures the coherence among the missiongovernance and accountability model.

In SGR sustainability orientation is the answer to a background of social responsibility and possible intrinsic motivation. Key distinctive aspects of the Group (and strengths) are the authentic and continuous engagement with stakeholders, and in particular with local communities, networks, schools and universities and the sustainable, transformational and ethical-based model of leadership. SGR a leading actor within the local (but also national and international) socio-economic fabric it belongs to and it drives the evolution and innovation of many actors. SGR wishes to be the leading actor in the improvement of the quality of life of a community. The relation-based and values/virtues based approach promoted by the leadership facilitates the growth of the company and the sustainability-driven process, reinforce the intrinsic motivations and favors changes over time (Bastons, 2008).

Accordingly, it can be said that the SGR Group is a sustainable company, based on a sustainable business models, thanks to the leadership model, who has inspired a variety of CSR and sustainability-oriented projects during the years and has firmly desired to implement the sustainability report. In other words, the leadership model is a transformational one and is directed to a virtues-based and sustainable leadership model which support the renewing and improving of the business model toward sustainability (Simons, 1999).

Despite the limitations related to the use of a qualitative approach, based on a single case study, and to the fact the research is still in progress, the works have implications both on the scientific and managerial/operational level. In fact previous studies did not address this topic using twofold interpretive keys (sustainability business model and virtues-based/ethical based and sustainable leadership); at the same time, the research project contributes to improve the learning of the sustainability-oriented process and sustainable leadership in the real business context, thus opening new trajectories, we hope, for the fruitful convergence between theory and practice. 


\section{Endnotes}

${ }^{1} \mathrm{We}$ can cite projects for kindergartens, elementary and middle children which involved more than 5,000 students aimed at educating to eco-energy, nutrition, civic sense, the creative and artistic development.

\section{Authors' contributions}

Please note that this paper represents the work of a common research project. However, DBM wrote sections: 2. Theoretical Framework (2.1Sustainable business models and 2.2.Sustainable business models and sustainable leadership), 3.1. (Methodology), 3.4. (Improving SGR's sustainable business model) and 5. (Conclusion) while BMG wrote sections: 1. Introduction; 3.2 (Company profile), 3.3 (SGR's Mission, Governance and Accountability) and 4. (Discussion). Both authors read and approved the final manuscript.

\section{Competing interests}

The authors declare that they have no competing interests. Mara Del Baldo

Maria Gabriella Baldarelli

\section{Publisher's Note}

Springer Nature remains neutral with regard to jurisdictional claims in published maps and institutional affiliations.

\section{Author details}

${ }^{1}$ Department of Economics, Society and Politics, University of Urbino Carlo Bo, Urbino, PU, Italy. 'Department of Management, and University Institute of Sophia, University of University of Bologna, Fl, Italy.

Received: 20 December 2016 Accepted: 9 March 2017

Published online: 24 March 2017

\section{References}

Abdelkafi, N. \& Täusher, K. (2015). Business Models for Sustainability from a System Dynamics Perspective, Organization Environment, July $2^{\text {nd }}$. doi: 10. $1177 / 1086026615592930$.

Adams, C. (2002). Internal Organizational Factors Influencing Social and Ethical Reporting: beyond Current Theorising. Accounting, Auditing and Accountability Journal, 15(2): 223-250.

Afuah, A. (2004). Business models: A strategic management approach. New York: Irwin/McGraw-Hill.

Afuah, A., \& Tucci, C. L. (2000). Internet business models and strategies: Text and cases. In McGraw-Hill Higher Education.

Amit, R., \& Zott, C. (2001). Value creation in E-Business. Strategic Management Journal, 22(6), 493-520.

Applegate, L. M. (2000). E-business models: Making sense of the internet business landscape. In G. Dickson \& G. DeSanctis (Eds.), Information technology and the future enterprise: New models for managers (pp. 49-101). Englewood Cliffs: Prentice-Hall.

Argyris, C. (1985). Action Science, Concepts, methods, and skills for research and intervention. San Francisco: Jossey Bass, Now.

Avery, G., \& H. Bergsteiner, H. (2011). Sustainable leadership practices for enhancing business resilience and performance. Strategy \& Leadership, 39(3) 5-15.

Baldarelli, M. G. (2005). Le aziende eticamente orientate. Mission, governance e accountability. In Collana diretta dal Prof. Antonio Matacena: "Il Nuovo Bilancio d'esercizio". Bologna: CLUEB.

Baldarelli, M. G. (2013). Account(ing)-ability and "charisma": conceptual network and implementation. Ekonomska Istrazivanja-Economic Research, 26(2), 63-82.

Baldarelli, M. G., \& Del Baldo, M. (2013). The Implementation of Sustainability Reporting in SGR Group: Some Challenges of Transition from Greenwashing to Relational Change. International Journal of Social Ecology and Sustainable Development, 4(2), 49-73. doi:10.4018/jsesd.2013040104.

Baldarelli, M. G., Del Baldo, M., \& Nesheva-Kiosseva, N. (2014). Implementing Sustainability Reporting (SR): (Neo-) Institutional Theory Insights in the Analysis of the SGR Group, Italy and CityGas, Bulgaria. Journal of Modern Accounting and Auditing, 10(11), 1067-1104.
Baldarelli, M. G., Del Baldo, M. \& Ferrone, C. (2015). The Relationships Between CSR, Good Governance and Accountability in the Economy of Communion (EoC) Enterprises. In Idowu, S.O., Frederiksen, C.S., Mermod, A.Y., Nielsen, M.E. J., Corporate Social Responsibility and Governance: Practice and Theory (pp. 3-38). Heidelberg: Springer International Publishing Switzerland.

Bass, B. M., \& Steidlmeier, P. (1999). Ethics, character, and authentic transformational leadership behavior. Leadership Quarterly, 10(2), 181-217.

Bastons, M. (2008). The role of virtues in the framing of decisions. Journal of Business Ethics, 78, 389-400.

Beattie, V., \& Smith, S. J. (2013). Value creation and business models: Refocusing the intellectual debate. The British Accounting Review, 45, 243-254.

Bebbington, J., Higgins, C., \& Frame, B. (2009). Initiating sustainable development reporting: Evidence from New Zealand. Accounting, Auditing, and Accountability Journal, 22(4), 588-625.

Benbasat, I., Goldstein, D. K., \& Mead, M. (1987). The case research strategy in studies of information-systems. MIS Quarterly, 11, 369-386.

Birkin, F., Cashman, A., Koh, S. C. L., \& Liu, Z. (2009). New sustainable business models in China. Business Strategy and the Environment, 18, 64-77.

Birkin, F., Polesie, T., \& Lewis, L. (2009). A new business model for sustainable development: an exploratory study using the theory of constraints in Nordic organizations. Business Strategy and the Environment, 18, 277-290.

Bocken, N. M. P., Short, S. W., Rana, P., \& Evans, S. (2014). A literature and practice review to develop sustainable business model archetypes. Journal of Cleaner Production, 65, 42-56

Boons, F., \& Lüdeke-Freund, F. (2013). Business models for sustainable innovation: state-of-the-art and steps towards a research agenda. Journal of Cleaner Production, 45, 9-19.

Boons, F. A. A., \& Mendoza, A. (2010). Constructing sustainable palm oil: how actors define sustainability. Journal of Cleaner Production, 18, 1686-1695.

Bouckaert, L. (2011). Spirituality and Economic Democracy. In L. Zsolani (Ed.), Spirituality and Ethics in Management (2nd ed., pp. 41-52). Dordrecht: Springer.

Broadbent, J. (1998). The Gendered Nature of 'Accounting Logic': Pointers to an accounting that encompasses multiple values. Critical Perspectives on Accounting, 9, 267-297.

Broadbent, J. (2015). A Gender Agenda. Paper for the SIDREA International Workshop Meditary Accountancy Research European Conference (pp. 1-14). Forli: University of Bologna. forthcoming Meditary Accountancy Research, pp.1-17.

Brougham, A. (2012). Discussion of 'Business-model (intent)-based accounting, Jim Leisenring, Thomas Linsmeier, Katherine Schipper and Edward Trott. Accounting and Business Research, 42(3), 345-347.

Brousseau, E., \& Penard, T. (2007). The economics of digital business models: a framework for analyzing the economics of platforms. Review of Network Economics, 6(2), 81-114

Brown, J. B. (2011). The Building of a Virtuous Transformational Leader. The Journal of Virtues and Leadership, 2(1), 6-14.

Bruni, L. (2008). Reciprocity, Altruism and the Civil Society: In Praise of Heterogeneity. New York: Routlege.

Bruni, L., \& Sena, B. (Eds.). (2013). The Charismatic Principle in Social Life. New York: Routledge

Bruni, L. \& Zamagni, S. (2007). Civil Economy. Oxford: Peter Lang.

Burns, H., Vaught, D., \& Bauman, C. (2015). Leadership for sustainability: theoretical foundations and pedagogical practices that foster change. International Journal of Leadership Studies, 9(1), 131-143.

Burritt, R., \& Schaltegger, S. (2010). Sustainability accounting and reporting: fad or trend? Accounting, Auditing \& Accountability Journal, 23, 829-846.

Capaldi, N. (2013). How American Spiritual Capital Inform Business and Affects the Common Good. In S. Groschl (Ed.), Uncertainty, Diversity and the common good. Changing Norms and New Leadership Paradigms (pp. 25-40). Surrey: Gower.

Cardona, P. (2000). Trascendental Leadership. Leadership and Organization Development Journal, 21(4), 201-206.

Casadesus-Masanell, R., Ricart, J.E. (2010). From strategy to business models and onto tactics. Long Range Planning, 43: 195-215.

Charter, M., Gray, C., Clark, T., \& Woolman, T. (2008). Review: the role of business in realising sustainable consumption and production. In A. Tukker, M. Charter C. Vezzoli, E. Stø, \& M. M. Andersen (Eds.), Perspectives on Radical Changes to Sustainable Consumption and Production 1. System Innovation for Sustainability (pp. 46-69). Sheffield: Greenleaf.

Choi, J. (2006). A motivational Theory of Charismatic Leadership: Envisioning, Empathy and Empowerment. Journal of Leadership \& Organizational Studies, 13(1), 24-43. 
Choi, Y., \& Mai-Dalton, R. R. (1998). On the leadership function of self-sacrifice. Leadership Quarterly, 9, 475-501.

Contrafatto, M. (2011). Social and environmental accounting and engagement research: Reflections on the state of the art and new research avenues. Economia Aziendale Online, 2(3), 273-289.

Del Baldo, M. (2010). Corporate Social Responsibility and Corporate Governance in Italian SMEs: Toward a 'territorial' Model based on Small 'champions' of CSR. International Journal of Sustainable Society, 2(3), 215-247.

Del Baldo, M. (2013). CSR-Oriented SMEs: A question of Entrepreneurial virtues in action? Reflections in Theory and Practice. In J. O. Okpara \& S. O. Idowu (Eds. ), Corporate Social Responsibility. Challenges, Opportunities and Strategies for 21st Century Leaders (pp. 145-170). Springer-Verlag: Berlin.

Del Baldo, M. (2014). Sustainable Entrepreneurship: Next Stage of Responsible Business. In C. Weidinger, F. Fischler, \& R. Schmidpeter (Eds.), Sustainable Entrepreneurship. Business success through sustainability (pp. 35-153). Berlin: Springer.

Del Baldo, M. (2016a). Authentic CSR and Leadership: toward a virtues-based model of stakeholders dialogue and engagement. The Loccioni Group experience. In S. O. Idowu \& S. Vertigans (Eds.), Stages of Corporate Social Responsibility: From Ideas to Impacts. Berlin Heidelberg: Springer.

Del Baldo, M. (2016b). From Theory to Practice or From Practice to Theory in implementing an effective CSR Approach? Insights from Italian Corporate Territorial Responsibility Projects. In M. Alcuhna \& S. O. Idowu (Eds.), The Dynamics of Corporate Social Responsibility. A Critical Approach in Theory and Practice. Berlin: Springer- Verlag.

Del Baldo, M., \& Baldarelli, M. G. (2015). From weak to strong CSR: the experience of the EoC (Economy of Communion) industrial parks in Germany and Italy. uwf UmweltWirtschaftsForum, 23(4), 213-226.

Dubosson-Torbay, M., Osterwalder, A., \& Pigneur, Y. (2002). E-business model design, classification, and measurements. Thunderbird International Business Review, 44(1), 5-23.

Dyllick, T., \& Hockerts, K. (2002). Beyond the business case for corporate sustainability. Business, Strategy and Environment, 11(2), 130-141.

Eisenhardt, K. M. (1989). Building Theories from Case Study Research. Academy of Management Review, 14(4), 532-550.

EU-Commission (2012). Social Innovation http://ec.europea.eu/enterprise/policies/ Innovation/policy/social-Innovation/index_en.htm. Accessed 11 Feb 2015

George, G., \& Bock, A. (2009). The business model in practice and its implications for entrepreneurship research. Working paper. London: Imperial College.

GRI - Global Reporting Initiative (2013). Sustainability Reporting Guideline-G4, May 2013. Available at: http://www.globalreporting.org. Accessed 2 Sept 2015

Gray, R. H., Dey, C., Owen, D., Evans, R., \& Zadek, S. (1997). Struggling with the Praxis of Social Accounting: Stakeholders, Accountability, Audits and Procedures. Accounting, Auditing \& Accountability Journal, 10(3), 325-364.

Hoivik von Weltzien, H. (2014). The Heart of Leadership is Ethics. Impresa Progetto-Electronic Journal of Management, 11, 1-9.

Hoivik von Weltzien, H., \& Melé, D. (2009). Can a SME Become a Global Corporate Citizen? Evidence from a Case study, Journal of Business Ethics, $88,551-562$.

IIRC. (2013b). Business Model Background Paper http://integratedreporting.org/ wp-content/uploads/2013/03/Business_Model.pdf. Accessed 10 Nov 2015

IIRC - International Integrated Reporting Council. (2013). The International $\langle\mathbb{R}\rangle$ Framework.

Johnson, M.W. (2010). Seizing the White Space. In: Business Model Innovation for Growth and Renewal. Boston, MA: Harvard Business School Press.

Jones, J. (2014). Leadership lessons from Levinas: revisiting responsible leadership. Leadership and the Humanities, 2, 44-63.

Kaptein, M. (2009). Ethics Programs and Ethical Culture: A Next Step in Unravelling their Multi-faceted Relationship. Journal of Business Ethics, 89(2), 261-281.

Kotnour, T. (2001). Building Knowledge for and about Large-scale Organisational Transformations. International Journal of Operations and Production Management, 21(8), 1053-1075. MCB, University Press, UK.

Leisenring, J., Linsmeier, T., Schipper, C., \& Trott, E. (2012). Business-model (intent)based accounting. Accounting and Business Research, 42(3), 329-344.

Lélé, S. (1991). Sustainable development: a critical review. World Development, 19(6): 607-621.

Linder, J. C., \& Cantrell, S. (2000). Changing Business Models: Surveying the Landscape. Accenture Institute for Strategic Change.

Liu, C. H. (2007). Transactional, Transformational, Transcendental Leadership: Motivation Effectiveness and Measurement of Transcendental Leadership. In Paper presented at 'Leading the Future of the Public Sector: The Third Transatlantic Dialogue' (pp. 1-26). Newark: University of Delaware.
Lloyd, H. R., \& Mey, M. R. (2010). An Ethics Model to Develop an Ethical Organisation. South African Journal of Human Resource Management, 8(1), 1-12.

Looser, S. \& Wehrmeyer, W. (2015). Doing well or doing good? Extrinsic and intrinsic CSR in Switzerland, UWF, DOI 10.1007/s00550-015-0360-9, 1-14, published on line August 14, 2015, Berlin Heidelberg: Springer-Verlag.

Lovins, A. B., Lovins, L. H., \& Hawken, P. (1999). A road map for natural capitalism. In Harvard Business Review. 1e14 (HBR paperback reprint 2000).

Lüdeke-Freund, F. (2009). Business Model Concepts in Corporate Sustainability Contexts. In From Rhetoric to a Generic Template for 'Business Models for Sustainability'. Lüneburg: Centre for Sustainability Management.

Magni, M., \& Pennarola, F. (2015). Responsible leadership - Creare benessere, sviluppo e performance a lungo termine. Milano: Egea.

Magretta, J. (2002). Why business models matter. Harvard Business Review, 80(5), $86-92$.

Malloch, T. R. (2009). Spiritual Enterprises. Doing Virtuous Business. New York: Encounter Books.

Martin, R.L. \& Osberg, S. (2007). Social entrepreneurship: The case for definition. Stanford Social Innovation Review, 5(2): 28-39.

Matacena, A. (2010). Corporate social responsibility and Accountabilty: Some Glosses. In M. G. Baldarelli (Ed.), Civil Economy, Democracy, Transparency and Social and Environmental Accounting Research Role (pp. 7-59). Milano: McGraw-Hill.

Melé, D. (2009). Business Ethics in action, Seeking Human Excellence in Organizations. NY: Palgrave McMillan.

Melé, D. (2012). Management Ethics. Placing ethics in the core of good Management. N.Y: Palgrave McMillan.

Miller, T. L., Grimes, M., McMullen, J., \& Vogus, T. J. (2012). Venturing for others with heart and head: How compassion encourages social entrepreneurship. Academy of Management Review, 37(4), 616-640.

Morris, M., Schindehutte, M., \& Allen, J. (2005). The entrepreneur's business model: towards a unified perspective. Journal of Business Research, 58, 726-735.

Morris, M. H., Shirokova, G., \& Shatalov, A. (2013). The Business Model and Firm Performance: The Case of Russian Food Service Ventures. Journal of Small Business Management, 51(1), 46-65.

Naumes, W., \& Naumes, M. J. (2006). The art and craft of case writing (2nd ed.). London: ME SHARPE Inc.

Nicholls, A., \& Murdock, A. (2012). The nature of social innovation. In A. Nicholls \& A. Murdock (Eds.), Social innovation: Blurring boundaries to reconfigure markets. London: Palgrave Macmillan.

Olsen, O. K. (2010). Are good leaders moral leaders? In The relationship between effective military operational leadership and morals. Bergen: Dissertation for the philosophiae doctor degree (PhD) at the University of Bergen.

Osterwalder, A., Pigneur, Y., \& Tucci, C. (2005). Clarifying business models: origins, present and future of the concept. Communications of the Association for Information Systems, 15, 1-38.

Page, M. (2014). Business models as a basis for regulation of financial reporting. Journal of Management and Governance, 18, 683-695.

Palshikar, K. (2007). Charismatic Leadership.

Penman, S. H. (2007). Financial reporting quality: is fair value a plus or a minus? Accounting and Business Research. International Accounting Policy Forum, $37(1), 33-44$

Porter, M. E., \& Kramer, M. R. (2011). Creating shared value. Harvard Business Review, 89(1/2), 62-77.

Rhode, D. L. (2006). Moral Leadership: The Theory and Practice of Power, Judgment and Policy (1st ed.). San Francisco: Jossey-Bass.

Richardson, J. (2008). The business model: An integrative framework for strategy execution. Strategic Change, 17(5/6), 133-144.

Rimondini, G. (2009). Gruppo Società Gas Rimini. 1959-2009, Cinquantesimo anniversario dall'inizio dell'erogazione del gas. Rimini: Società Gas Rimini.

Roome, N., \& Louche, C. (2016). Journeying Toward Business Models for Sustainability: A Conceptual Model Found Inside the Black Box of Organisational Transformation. Organization \& Environment, 29, 11-35.

Ruisi, M. (2010). Measure Entrepreneurial Virtues. Towards a new perspective for the indicators of corporate success. In Paper presented at the 23rd Eben Annual Conference (pp. 9-11). Trento: Which values for which Organisations?.

Salzmann, O., lonescu-Somers, A., \& Steger, U. (2005). The business case for corporate sustainability: literature review and research options. European Management Journal, 23(1), 27-36.

Sankaran, S., \& Tay, B. H. (2003). Action Research Models in Business Research. East Lismore: Southern Cross University. 
Sansone, F. (2014). Leadership responsabile. Le 10 regole per essere leader nell'economia della conoscenza. Milano: F. Angeli.

Schaltegger, S., Lüdeke-Freund, F., \& Hansen, E. G. (2012). Business cases for sustainability: The role of business model innovation for corporate sustainability. International Journal of Innovation \& Sustainable Development, 6(2), 95-119.

Schaltegger, S., Hansen, E. G., \& Lüdeke-Freund, F. (2016). Business Models for Sustainability: Origins, Present Research, and Future Avenues. Organization \& Environment, 29(1), 3-10.

Seelos, C., \& Mair, J. (2005). Social entrepreneurship: creating new business models to serve the poor. Business Horizons, 48, 241-246.

Seelos, C., \& Mair, J. (2006). Social entrepreneurs e the contribution of individual entrepreneurs to sustainable development. The ICFAl Journal for Entrepreneurship Development, 30, 46.

Seelos, C., \& Mair, J. (2007). Profitable business models and market creation in the context of deep poverty: A strategic view. Academy of Management Perspectives, 21, 49-63.

Seligman, M. E. (2004). Character, Strenghts and Virtues. New York: Oxford University Press.

Shafer, S. M., Smitha, H. J., \& Linder, J. C. (2005). The Power of Business Models. Business Horizons, 48, 199-207.

Shamir, B., House, R. J., \& Arthur, M. B. (1993). The motivational effects of charismatic leadership: A self-concept based theory. Organization Science, 4(4), 577-594.

Simons, T. L. (1999). Behavioral integrity as a critical ingridient for transformational leadership. Journal of Organizational Change Management, 12, 89-104.

Singleton-Green, B. (2014). Should financial reporting reflect firms' business models? What accounting can learn from the economic theory of the firm. Journal of Management \& Governance, 2014, vol. 18, issue 3, pages 697-706.

Spence, C., \& Gray, R. (2008). Social and environmental reporting and the business case. London: ACCA.

Stewart, D. W., \& Zhao, Q. (2000). Internet marketing, business models and public policy. Journal of Public Policy and Marketing, 19, 287-296.

Stubbs, W., \& Cocklin, C. (2008). Conceptualizing a 'sustainability business model'. Organization \& Environment, 21, 103-127.

Teece, D. J. (2010). Business Models, Business Strategy and Innovation. Long Range Planning, 43, 172-194.

Timmers, P. (1998). Business models for electronic markets. Electronic Markets, 8(2), 3-8.

Tukker, A., Charter, M., Vezzoli, C., Stø, E., \& Andersen, M. M. (Eds.). (2008). Perspectives on Radical Changes to Sustainable Consumption and Production. Sheffield: Greenleaf.

Visser, W. (2011). The Nature of CSR Leadership. Definitions, Characteristics and Paradoxes. CSR International Paper Series, 4, 1-10.

Von Ahsen, A. (2015). Sustainability Leadership. In S. O. Idowu, N. Capaldi, M. Fifka, L. Zu, \& R. Schmidpeter (Eds.), Dictionary of Corporate Social Responsibility (p. 444). Heidelberg: Springer.

Walker, T. (2015), Entrepreneurial Wisdom. Paper presented at the 2nd International Conference on CSR, Sustainability, Ethics and Governance, Nanjing, China, July 29-31, 2015 2015_01_Entrepreneurial_Wisdom_Walker_ final.docm,pp 1-12. walk-on Institute for sustainable solutions. www.walk-on. co.at [Accessed 18 Jan 2016]

Walker, B., \& Salt, D. (2006). Resilience thinking: sustaining ecosystems and people in a changing world. Washington: Island Press.

Weill, P., \& Vitale, M. R. (2001). Place to space: Migrating to e-business models. Boston: Harvard Business School Press.

Wells, P. (2008). Alternative business models for a sustainable automotive industry. In A. Tukker, M. Charter, C. Vezzoli, E. Stø, \& M. M. Andersen (Eds.), Perspectives on Radical Changes to Sustainable Consumption and Production 1 (System Innovation for Sustainability, pp. 80-98). Sheffield: Greenleaf.

Werhane, P. (1999). Moral Imagination and Management Decision Making. Oxford: University Press.

Westbrook, R. (1994). Action Research: a new paradigm for research in Production and Operation Management. International Journal of Operations and Production Management, 15(12), 6-20. MBC, University Press, UK.

Yin, R.K. (2003). Case Study Research. Design and Methods. London: Sage Publications, 3rd ed.

Zott, C., \& Amit, R. (2010). Business Model Design: An Activity System Perspective. Long Range Planning, 43, 216-226.

Zott, C., Amit, R., \& Massa, L. (2011). The Business Model: Recent Developments and Future Research. Journal of Management, 37(4), 1019-1042.

\section{Submit your manuscript to a SpringerOpen ${ }^{\circ}$ journal and benefit from:}

- Convenient online submission

- Rigorous peer review

- Immediate publication on acceptance

- Open access: articles freely available online

- High visibility within the field

- Retaining the copyright to your article

Submit your next manuscript at springeropen.com 